\title{
Assessment of ethno-veterinary practices in small ruminants in Akinyele local government area, Ibadan, Oyo state, Nigeria
}

\author{
${ }^{* 1}$ Unigwe, C.R., ${ }^{2}$ Enibe, F., ${ }^{1}$ Egwu, L.U., ${ }^{1}$ Otuh, P.I. \& ${ }^{1}$ Onyeachonam, F.O.
}

${ }^{I}$ Department of Veterinary Biochemistry of Veterinary Medicine, Michael Okpara University of Agriculture, Umudike, Abia State, Umuahia, Abia State, ${ }^{2}$ Department of Veterinary Medicine, University of Ibadan, Oyo State, Nigeria, Ibadan, Oyo State, Nigeria.

*Corresponding author: robinsonunigwe@gmail.com, +2348037707965

\begin{abstract}
The application of traditional medicine to veterinary medicine has been termed ethno-veterinary medicine. Interview survey was conducted using a structured questionnaire to generate data on ethno-veterinary medicinal (EVM) practices used for treating pests and diseases of small ruminants in Akinyele Local Government Area, Oyo State, Nigeria. Information from one hundred and nine respondents was obtained through a multi-stage sampling technique. The data were analysed using simple descriptive statistics to generate frequencies and percentages. Demographic characteristics of the respondents showed that $62.39 \%$ were males and majority of them fell within $41-50$ year, married (48.62\%), Christians (68.81\%), practiced extensive system of rearing $(83.49 \%)$ with all of them into goat farming $(100 \%)$ and $30.28 \%$ also having sheep in addition to goats. Secondary level education $(38.53 \%)$ was the most attended by respondents. Majority sourced their EVM from family and relatives $(76.15 \%)$, whereas greatest causes of loss, constraint and ill-health were diseases $(46.79 \%)$, feed resources $(35.78 \%)$ and PPR (35.78\%) respectively. Most of them agreed that EVM has medicinal value (91.74\%), cheaper than orthodox drugs (93.58\%), has side effects (52.29\%) and also easier to administer (77.06\%). Eighteen (18) plant products that include fruit, leaf, root and bark were used to treat various diseases such as mange, cough, mastitis, diarrhoea, PPR, anthrax and snake bite. It is therefore recommended that these findings be used as baseline information by identifying the effective herbal remedies for livestock health which can be utilized by veterinarians and pharmacologists for the development of new therapies as well as isolation of bioactive compounds.
\end{abstract}

Keywords: Animal diseases, ethno-veterinary practices, small ruminants, socio-economic

\section{INTRODUCTION}

Animal protein is regarded as a first class protein in the diets of humans because it supplies all the essential amino acids needed for the body to perform its biological functions. Livestock does not only supply protein to the body, it serves to be a repository of wealth, earning foreign exchange and enhancing the economy of a country. Unfortunately, there are setbacks occasioned by diseases that could lead to low productivity or even ultimately death. Conventional chemotherapeutic agents are either too expensive or outrightly unavailable to manage disease(s). Poor animal health is an important factor limiting animal productivity in most developing countries including Nigeria, there has been a decline in funding for veterinary services and animal- health care in general. For these reasons, most of the animals kept by herdsmen and other village producers are not accessed easily by veterinary personnel (Mishra, 2013). The indigenous knowledge existed among various traditional practitioners, elderly people, bone setters, hunters, including herdsmen who are knowledgeable about medicinal plants' utilization which they use to meet the needs and expectations of populace (Abdulhamid et al., 2017)., there arises the exigency to resort to ethnoveterinary medicine (EVM) to challenge the disease in the animal. Moreover, pastoralists depend on EVM because of their sedentary nature, which keep them far away from Veterinarians (Rahmatullah et al., 2010). 
Medicinal plants have been used for chemotherapeutic purpose across the globe since ages due to their efficacy and availability as well as cultural beliefs (Rafique et al., 2021). According to Brouwer et al. (2005), approximately $25 \%$ of all pharmaceutical products worldwide originated from traditional medicinal knowledge and there is widespread interest in developing new types of medicinal agents with greater potency and reduced side effects. EVM is a system that is based on people's beliefs, indigenous knowledge, skills, methods and practices used for curing diseases and maintaining health of animals which are transmitted from generation to generation through oral communication without any formal documentation (Mathias-Mundy \& McCorkle, 1989; Tabuti et al., 2003; Birhanu \& Abera, 2015). In other studies (Nok et al., 1993; Nok \& Williams, 1996), the active principles as well as the mechanisms of action of some plant extracts that are used in ethnoveterinary medicine have been established, thus suggesting the potential of traditional drugs in primary animal-health care. There are reports of farmers using traditional remedies because they are more readily available and cheaper Chah et al. (2009), Kubkomawa et al. (2013), Tariq et al. (2014) and Hart \& Bussmann, (2018) and additionally, EVM is partly effective and practicable in animal diseases treatment (Kaikabo et al., 2004).

Although similar works have been done in other areas of Nigeria including Oyo state but Akinyele Local Government Area, Ibadan, Oyo State, Nigeria has paucity of information on the theme despite its abundant small ruminant population. Therefore, this study was conducted to evaluate the EVM practices among small ruminants' farmers in this study area.

\section{METHOLOGY}

\section{THE STUDY AREA}

The study was conducted at Akinyele Local Government Area (LGA), Oyo State, Nigeria. It is one of the eleven LGAs that make up Ibadan metropolis and comprises both urban and rural parts with Moniya as the Headquarters. It has an area of $518 \mathrm{~km}^{2}$ and a population of 105, 594 males and 106, 217 females (NPC, 2006). The LGA was created in 1976 and shares boundaries with Afijo to the North, Lagelu to the East, Ido to the West and Ibadan-North LGAs to the South. It occupies a land area of $464,892 \mathrm{~km}^{2}$ with a population density of 516 persons per square kilometre. Its geographic coordinates are $7^{\circ} 23^{\prime} 47^{\prime \prime} \mathrm{N}$ and longitude $3^{\circ} 55^{\prime}$ 0" E (Efenakpo et al., 2016). The LGA is subdivided into 12 Wards, namely Ikereku, Olanla/Oboda/Labode, Arulogun/Eniosa/Aroro, Olode/Amosun/Onidundu, Akinyele/Isabiyi/Irepodun, Ojo-emo/Moniya, Iwokoto/Talonta/Idi-oro, Ojoo/Ajibode/Laniba and Ajibade/Alabata/Elekuru. Others include Ijaye/Ojedeji, Olorisa-oko/Okegbemi/Mele, and Iroko. The LGA houses the major Central Abattoir of Ibadan Metropolis and has large population of small ruminants.

\section{ETHICAL STATEMENT}

Code of ethics of International Society of Ethnobiology (2008) was followed during data collection. The respondents were initially briefed about the purpose of this research work and verbal consents were obtained from all of them. Most of the respondents were illiterate and obtaining written consent from them was impossible.

\section{SOURCE OF DATA AND SAMPLING PROCEDURE AND SIZE}

The methods used for ethno-veterinary practice data collection were semi-structured interviews and field observation (Bouyahya et al., 2017). Questionnaires as standardized data collection protocols (Martin, 2004; Ocvirk et al., 2013) were used to elicit information on ethnoveterinary management of small ruminants from the farmers at the study area between February and March, 2017. Open ended questions and field observation were used to identify the medicinal plants used, information on pests and diseases of small ruminants, medicinal value of each medicinal plants and its method of administration through key informants' interviews and focus group discussion (FGDs). The LGA was purposively selected because of the abundance of subsistent small ruminant farmers. Multi-stage sampling technique was used for the study. Households that cut across the 12 Wards rearing small ruminants were enumerated and ten farmers randomly selected from each of them for administration of questionnaires and conduct of field survey. Therefore, a total of 120 small ruminant (sheep and goats) farmers were selected. More often, they were accompanied to the field for identification of plant species used in the EVM. To bring an element of accuracy, the information obtained from one locality was cross-checked with that of others. Specimens of medicinal plants collected from each locality were provided with a collection voucher number for future reference. The plant specimens were processed at the Herbarium of Federal College of Animal Health and Production Technology, Ibadan, Oyo State, Nigeria and then identified with the help of available literature (Abbasi et al., 2013; Akobundu et al., 2016; Aziz et al., 2018).

\section{DATA ANALYSIS}

The data collected were presented using descriptive (such as frequency counts, percentages and means) and inferential statistics. 


\section{RESULTS}

\section{SOCIO-ECONOMIC CHARACTERISTICS OF THE RESPONDENTS}

One hundred and nine (109) out of one hundred and twenty (120) questionnaires distributed were recovered. Table I shows the socio-economic characteristics of the respondents. The results showed that most of the respondents were within the age range of $41-50(40.37 \%)$, followed by $31-40(22.02 \%), 21-30(18.35 \%)$ and whereas the least was $10-20(3.67 \%)$ years. Males $(62.39 \%)$ were the greater respondents. Married people $(48.62 \%)$ assumed the greatest proportion, followed closely by the singles $(43.20 \%)$ and the least been the widowed $(3.67 \%)$ people. Christians $(68.81 \%)$ also constituted the greater portion as opposed to Islam (31.19\%). In terms of household size, $1-5(53.21 \%)$ was the most populous followed by $6-10(42.20 \%), 11-15$ $(3.67 \%)$ and the least was $>15(0.92 \%)$ people. The respondents practiced extensive system $(83.49 \%)$ and semi-intensive $(16.51 \%)$ whereas no one practiced intensive system of raising animals. Every respondent reared goat while 34 of them practiced mixed farming of sheep and goat. Most of them had flock size of $1-10$ $(51.38 \%)$ followed by $11-20(43.12 \%), 21-30$ (3.67\%), $31-40$ (1.83\%) and none had above 40 animals. Majority of the people had been in the small ruminant rearing for the past $6-10$ $(62.39 \%)$ years. Most of the farmers had secondary education $(38.53 \%)$, followed by tertiary $(31.19 \%)$ and primary $(16.51 \%)$ whereas the holders of non-formal education $(13.76 \%)$ were the least. Majority had their primary occupation as farming $(37.61 \%)$ followed by trading $(22.02 \%)$ and artisan and civil service $(20.18 \%)$. Thirty three percent $((33 \%)$ of the respondents had a monthly earning of more than N40,000:00.

\section{SOURCES OF INFORMATION ON ETHNOVETERINARY KNOWLEDGE USED IN TREATING SMALL RUMINANTS}

Table II shows the sources of information on ethnoveterinary knowledge used in treating small ruminants in the study area. The results showed that most respondents (76.15\%) got their information from family and relatives. Similarly, $67.89 \%$ got theirs from friends. Extension agents contributed $15.60 \%$ of the information whereas books, radio, television and trial/error contributed 11.01, 10.09, 7.34 and $4.59 \%$ respectively.
Table I: Socio-economic characteristics of the respondents $(n=?)$

\begin{tabular}{|c|c|c|c|c|c|}
\hline Variable & Frequency & $\begin{array}{l}\text { Percent } \\
\text { age }(\%)\end{array}$ & & Freq & $\%$ \\
\hline Age (years) & & & Flock size & & \\
\hline $10-20$ & 04 & 3.67 & $1-10$ & 56 & 51.38 \\
\hline $21-30$ & 20 & 18.35 & $11-20$ & 47 & 43.12 \\
\hline $31-40$ & 24 & 22.02 & $21-30$ & 04 & 3.67 \\
\hline $41-50$ & 44 & 40.37 & $31-40$ & 02 & 1.83 \\
\hline $51-60$ & 09 & 8.27 & $>40$ & 0.00 & 0.00 \\
\hline$>60$ & 08 & 7.34 & $\begin{array}{r}\text { Length of } \\
\text { time in the } \\
\text { rearing } \\
\text { (year) }\end{array}$ & & \\
\hline Sex & & & $1-5$ & 33 & 30.28 \\
\hline Male & 68 & 62.39 & $6-10$ & 68 & 62.39 \\
\hline Female & 41 & 37.61 & $11-15$ & 06 & 5.50 \\
\hline $\begin{array}{r}\text { Marital } \\
\text { status }\end{array}$ & & & $>15$ & 02 & 1.83 \\
\hline Single & 47 & 43.20 & $\begin{array}{r}\text { Level of } \\
\text { education }\end{array}$ & & \\
\hline Married & 53 & 48.62 & $\begin{array}{l}\text { No formal } \\
\text { education }\end{array}$ & 15 & 13.76 \\
\hline Divorced & 05 & 4.59 & $\begin{array}{r}\text { Primary } \\
\text { education }\end{array}$ & 18 & 16.51 \\
\hline Widowed & 04 & 3.67 & $\begin{array}{r}\text { Secondary } \\
\text { education }\end{array}$ & 42 & 38.53 \\
\hline Religion & & & $\begin{array}{r}\text { Tertiary } \\
\text { education }\end{array}$ & 34 & 31.19 \\
\hline Islam & 34 & 31.19 & $\begin{array}{r}\text { Primary } \\
\text { occupation }\end{array}$ & & \\
\hline Christianity & 75 & 68.81 & Artisan & 22 & 20.18 \\
\hline $\begin{array}{r}\text { Household } \\
\text { size }\end{array}$ & & & Farming & 41 & 37.61 \\
\hline $1-5$ & 58 & 53.21 & Trading & 24 & 22.02 \\
\hline $6-10$ & 46 & 42.20 & Civil service & 22 & 20.18 \\
\hline $11-15$ & 04 & 3.67 & $\begin{array}{c}\text { Income level } \\
\text { (A monthly) }\end{array}$ & & \\
\hline$>15$ & 01 & 0.92 & $<20,000$ & 20 & 18.35 \\
\hline $\begin{array}{r}\text { Farming } \\
\text { system }\end{array}$ & & & $\begin{array}{r}20,000- \\
29,999\end{array}$ & 34 & 31.19 \\
\hline Extensive & 91 & 83.49 & $\begin{array}{r}30,000- \\
39,999\end{array}$ & 19 & 17.43 \\
\hline Semi- & 18 & 16.51 & $>40,000$ & 36 & 33.03 \\
\hline
\end{tabular}

VARIABLES THAT INFLUENCED ILL-HEALTH IN SMALL RUMINANTS

Table III shows the results of variables that influenced illhealth in small ruminants. The results showed that most of the losses encountered were due to diseases $(46.79 \%)$ 
Table II: Sources of information on ethnoveterinary knowledge used in treating small ruminants

\begin{tabular}{rlll}
\hline Sources & Frequency & $\begin{array}{l}\text { Percentage } \\
(\%)\end{array}$ & Rank \\
\hline $\begin{array}{r}\text { Family and } \\
\text { relatives }\end{array}$ & $83^{*}$ & 76.15 & $1^{\text {st }}$ \\
Friends & $74^{*}$ & 67.89 & $2^{\text {nd }}$ \\
Extension agent & 17 & 15.60 & $3^{\text {rd }}$ \\
Books & $12^{*}$ & 11.01 & $4^{\text {th }}$ \\
Radio & 11 & 10.09 & $5^{\text {th }}$ \\
Television & 08 & 7.34 & $6^{\text {th }}$ \\
Trial and error & 05 & 4.59 & $7^{\text {th }}$ \\
\hline
\end{tabular}

followed by accident (32.11\%) and parasitism (21.10\%). In rearing the animals, the highest constraint was attributed to feed resources $(35.78 \%)$, followed by theft $(32.11 \%)$, diseases/parasitism (16.51\%) and the least was space for rearing $(15.60 \%)$. Amongst diseases experienced, PPR (35.78\%) was top-most followed by diarrhoea (29.36\%), mange $(12.84 \%)$, foot rot $(11.93 \%)$ and bloat $(10.09 \%)$. In terms of managing ill-health, traditional treatment $(35.78 \%)$ was mostly used as compared to zero treatment (29.36\%), orthodox medication (22.02\%) and mixture of orthodox and traditional medications $(12.84 \%)$.

\section{KNOWLEDGE ON THE USE OF TRADITIONAL TREATMENT}

Table IV shows the knowledge on the use of traditional medicine. The results showed that majority of the respondents agreed that traditional medicine had medicinal value $(91.74 \%)$, can be used to treat animals $(85.32 \%)$, cheaper than orthodox drugs $(93.58 \%)$, has side effects $(52.29 \%)$, more readily available $(82.57 \%)$, easier to administer $(77.06 \%)$ and animals perform better with it $(57.80 \%)$. While a greater number of respondents disagreed that EVM was more effective than orthodox medicine $(54.13 \%)$ in treating diseases of small ruminants, that animals can survive only on traditional medicine $(56.88 \%)$ and vaccination and orthodox medicines are not necessary $(65.14 \%)$.

\section{TRADITIONAL TREATMENTS FOR DISEASES OF SMALL RUMINANTS}

Table $\mathrm{V}$ shows traditional treatments for diseases of small ruminants in the study area. Mange, cough, mastitis, malnutrition, helminthosis, diarrhoea, footrot, bloat, flea and tick infestations, PPR (pestes des petit ruminants), anthrax and snake bite were the diseases for which they claimed to have traditional treatments. A skin disease such asmange can be treated with topical application of a mixture of palm oil, ground sunflower leaves, engine oil, kerosene and gammalin as well as ground bark of Khaya senegalensis and leaves of
Table III: Variables that influenced ill-health in small ruminants

\begin{tabular}{|c|c|c|}
\hline Variable & Frequency & $\begin{array}{c}\text { Percentage } \\
(\%)\end{array}$ \\
\hline \multicolumn{3}{|l|}{ Cause of death } \\
\hline Disease & 51 & 46.79 \\
\hline Parasitism & 23 & 21.10 \\
\hline Accident & 35 & 32.11 \\
\hline \multicolumn{3}{|l|}{$\begin{array}{l}\text { Constraints } \\
\text { raising animals }\end{array}$} \\
\hline Disease/parasitism & 18 & 16.51 \\
\hline Theft & 35 & 32.11 \\
\hline Feed resources & 39 & 35.78 \\
\hline Space for rearing & 17 & 15.60 \\
\hline \multicolumn{3}{|l|}{$\begin{array}{l}\text { Most encountered ill- } \\
\text { health }\end{array}$} \\
\hline PPR & 39 & 35.78 \\
\hline Diarrhoea & 32 & 29.36 \\
\hline Mange & 14 & 12.84 \\
\hline Bloat & 11 & 10.09 \\
\hline Foot rot & 13 & 11.93 \\
\hline $\begin{array}{l}\text { Management of } \\
\text { disease }\end{array}$ & & \\
\hline $\begin{array}{l}\text { Orthodox and } \\
\text { traditional } \\
\text { medications }\end{array}$ & 14 & 12.84 \\
\hline Orthodox medication & 24 & 22.02 \\
\hline Traditional medication & 39 & 35.78 \\
\hline No treatment & 32 & 29.36 \\
\hline
\end{tabular}

Nicotiana tabacum. Cough could be cured by drenching the diseased small ruminant with a mixture of palm kernel oil, juice of lime citrus fruit and Bridelia ferruginea bark soaked in water for 24 hours. The remedy for mastitis was a drench of cooked Spondias monbim leaf, while malnutrition wascured by grinding and feeding a mixture of Moringa oleifera and Leucaena leucocephala leaves to the animals. Helminthosis was treated with drench of pawpaw leaf and unripe pawpaw fruit soaked in water or grinding and drenching of the animal with Khaya senegalensis bark while diarrhoea was treated with either a drench of groundPhyllanthus amarus leaves, or soaked onion (in water) or feeding the animal with cooked maize. Alternatively, helminthosis was also treatable by drenching squeezed out bitter leaf water. Footrot was taken care of by applying a mixture of Aloevera and lime fruit (Citrus aurantifolia) on 
Table IV: Knowledge on the use of traditional medicine

\begin{tabular}{lcccc}
\hline Questions & Agree & $\begin{array}{c}\text { S. } \\
\text { agree }\end{array}$ & Disagree & $\begin{array}{c}\text { S. } \\
\text { disagree }\end{array}$ \\
\hline $\begin{array}{l}\text { Trad. med. has } \\
\text { medicinal value }\end{array}$ & 75 & 25 & 6 & 3 \\
$\begin{array}{l}\text { Trad. med.can be used } \\
\text { to treat animal }\end{array}$ & 59 & 34 & 12 & 4 \\
$\begin{array}{l}\text { Trad. med. is more } \\
\text { effective than }\end{array}$ & 35 & 15 & 46 & 13 \\
$\begin{array}{l}\text { orthodox drugs } \\
\text { Animals survive only } \\
\text { on the use of trad. }\end{array}$ & 38 & 9 & 39 & 23 \\
$\begin{array}{l}\text { med. } \\
\text { Trad. med. are } \\
\text { cheaper than orthodox } \\
\text { drugs }\end{array}$ & 61 & 41 & 4 & 3 \\
$\begin{array}{l}\text { Vaccination and } \\
\text { orthodox med. are not } \\
\text { necessary }\end{array}$ & 31 & 7 & 41 & 30 \\
$\begin{array}{l}\text { Trad. med. has side } \\
\text { effects } \\
\text { Trad. med.is more } \\
\text { readily available }\end{array}$ & 39 & 18 & 43 & 9 \\
$\begin{array}{l}\text { Trad. med. is easier to } \\
\text { administer } \\
\text { Animals perform } \\
\text { better with trad. med. }\end{array}$ & 57 & 27 & 18 & 7 \\
\hline
\end{tabular}

the affected foot whereas bloat was cured using palm oil drench. Flea and tick infestations were treated by rubbing palm oil and palm kernel oil respectively on the affected skin. Pestis des petit ruminants (PPR) received cure by topical application of ground mixture of Adansonia digitata and alligator pepper as well as grinding and drenching with Phyllanthus amarus leaf. Anthrax was managed with a drench of ground mixture of bitter leaf (Vernonia amygdalina) and lime (Citrus aurantifolia) fruit. Whereas, snake bite was treated with drench of ground Anona senegalensis bark and Diospyrus mespitiformis root.

\section{DISCUSSION}

The results in Table I show that a greater proportion of the rural people practicing EVM were within the age range of 41-50 years which agrees with the findings of Nnadi et al. (2012) and Ojo et al. (2014) that got 36-50 years. It infers that the study area was dominated by farmers who were still in their active ages and can thus engage actively in agricultural production. It was observed that old age population groups possessed more ethnobotanical knowledge because of their higher association with typical agro-pastoral lifestyle as compared to the younger generation (Heinrich et al., 2009).

Greater number of males in the demographic characteristics supports the observation that in most African societies, males are the head of the household (Chimonyo et al., 1999). Also, in the Northern Nigeria, males were reported to be the ones involved mostly in the activities of farming, hunting and marketing (Mudansiru et al., 2016; Ebbo et al., 2019). This however, was contradicted by Osho \& Fasina (2013) \& Ojo et al. (2014) in Ekiti State, that more women were involved in ethnoveterinary practice than men. That the majority of the respondents were married justifies the fact that $41-50$ year old people dominated the practice and it is in consonance with the findings of Omotara \& Olutegbe (2015) in Obokun Local Government Area of Osun State. That Christianity was in greater proportion is a function of location and religious belief of the people. Similarly, Ojo et al. (2014) got dominance of Christianity at Ekiti State where they surveyed ethno-veterinary practice in ruminants.

The dominance of extensive system of management in the study area agrees with findings of Safilios (1983) that the most common system throughout the developing countries involves the extensive system. The practice of subsistence farming by the respondents is similar to the finding of Adedeji et al. (2013) in Ona-Ara Local Government of Oyo State that was characterized by small flock size dominated by goats possibly because of preference of goat meat to mutton in the Southern Nigeria. In the same vein, Omotara \& Olutegbe (2015) got more goat farmers in Ekiti State. The length of time into rearing showed that they are experienced in animal husbandry. Because of the urban status of the study area, many that practiced EVM were educated unlike informal education that dominates similar settings particularly in typical rural areas (Ojo et al., 2014; Omotara \& Olutegbe, 2015). The primary occupation was mostly farming. This agrees with the finding of Ebbo et al. (2019) within Sokoto Metropolis, Nigeria. Most of them made N20,000 - N29,999 monthly suggesting that the business is profitable.

The results on sources of information align with several authors (Menale \& Muoio, 2014: Birhanu \& Abera, 2015) who have documented the passage of ethnoveterinary

knowledge orally among family with preference to old age group as secret and protection of their cultural heritage. This finding is in support of Fullas (2010) and Omotara \& Olutegbe (2015) who observed that similar to traditional knowledge, ethno-veterinary medicinal plant knowledge is not documented. It is simply transferred verbally from generation to generation and thus risks the danger of extinction. This mode of knowledge transfer may lead to interrupted knowledge transmission; intergenerational knowledge erosion and its effects are discrepancies between knowledge and actual use of medicinal plants (Srithi et al., 2009; Buwa-komoreng et al., 2019). 
Table V: Traditional treatments for diseases of small ruminants

\begin{tabular}{|c|c|c|c|}
\hline Disease & Treatment & Local name & Application method \\
\hline \multirow[t]{8}{*}{ Mange } & Palm oil & Epo pupa & Apply on the skin \\
\hline & Sun flower leaf & Sepelupa & Apply on the skin \\
\hline & Engine oil & Epo brake & Apply on the skin \\
\hline & Kerosene & Baafin & Apply on the skin \\
\hline & Gammalin & Gamale & Apply on the skin \\
\hline & Khaya senegalensis bark & Oganwo & Grind and apply on the skin \\
\hline & Nicotiana tabacum leaf & Taba & Grind and apply on the skin \\
\hline & Curcuma longa L (turmeric) & & Grind and apply on the skin \\
\hline \multirow[t]{2}{*}{ Cough } & Palm kernel oil + lime citrus & Adin eyan & Drench the animal \\
\hline & $\begin{array}{l}\text { Bridelia ferruginea bark } \\
\text { soaked in water }\end{array}$ & Ira & Drench the animal \\
\hline \multirow[t]{2}{*}{ Mastitis } & Spondias monbim leaf & Iyeye & Drench the animal \\
\hline & Curcuma longa L (turmeric) & & Drench the animal \\
\hline Malnutrition & $\begin{array}{l}\text { Moringa oleifera }+ \text { Leucaena } \\
\text { leucocephala }\end{array}$ & Leucena & $\begin{array}{l}\text { Grind the leaves and feed } \\
\text { the animals }\end{array}$ \\
\hline \multirow[t]{3}{*}{ Helminthosis } & Pawpaw leaf & Ewe ibepe & Soak in water and drench \\
\hline & Unripe pawpaw fruit & Ibepe dudu & Soak in water and drench \\
\hline & Khaya senegalensis bark & Oganwo & Grind and drench the animal \\
\hline \multirow[t]{4}{*}{ Diarrhoea } & Phyllanthus amarus leaf & Eyin olobe & Grind and drench the animal \\
\hline & Onion & Alubosa & Soak in water and drench \\
\hline & Cooked maize & Agbado sise & Feed the animal \\
\hline & Bitter leaf & Ewuro & Squeeze in water and drench \\
\hline Foot rot & $\begin{array}{l}\text { Aloevera + Lime (Citrus } \\
\text { aurantifolia) }\end{array}$ & Aloe & Grind and apply on the foot \\
\hline Bloat & Palm oil & Epo pupa & Drench the animal \\
\hline Flea & Palm oil & Epo pupa & Rub on the body \\
\hline Tick & Palm kernel oil & Adi-agbon & Rub on the body \\
\hline \multirow[t]{2}{*}{ PPR (kata) } & $\begin{array}{l}\text { Adansonia digitata \& } \\
\text { Alligator pepper }\end{array}$ & Lulu \& ose & Grind and rob on the lesions \\
\hline & Phyllanthus amarus leaf & Eyin olobe & Grind and drench \\
\hline Anthrax & Bitter leaf + Lime & Ewuro lime & $\begin{array}{l}\text { Grind them and drench the } \\
\text { animal daily }\end{array}$ \\
\hline \multirow[t]{2}{*}{ Snake bite } & Anona senegalensis bark & No name & Grind, boil and drench \\
\hline & Diospyrus mespitiformis root & No name & Grind and drench \\
\hline
\end{tabular}

during the first half of the year. The use of traditional medicine was the most popular among the respondents. Similar to the current study, Adeniran et al. (2020) reported that $46 \%$ of respondents indicated that they used herbal remedies exclusively to manage animal health conditions, $40 \%$ used both EVM and orthodox drugs while only $14 \%$ relied on orthodox veterinary preparations alone. The use of medicinal plants exclusively in the treatment of diseases of animals has been documented by Gras et al. (2018).

The respondents agreed that EVM has medicinal values, cheaper, more readily available, easier to administer and that animals perform better with it over orthodox medicines. These observations are at par
Ojo et al. (2014) reported massive death of goats due to different diseases. Animal diseases in general and infectious ones in particular are the major constraints to crop and livestock production in the humid and sub humid parts of the African continent (Palling \& Dwinger, 1993). Moreki et al. (2010) reported order of importance the major causes of losses in sheep and goats to include diseases, predation and a combination of diseases, parasites and predation. Feed cost is acknowledged to be the greatest constraint of raising small ruminants in the study area. This is in consonance with the report of Offor et al. (2018) who noted that cost of feeding small ruminants was the greatest constraint. Poor nutrition has always been considered as the most critical factor in livestock production, but in recent times, diseases cause more economic losses (FAO, 2016). The most encountered ill-health was pestes des petit ruminant (PPR) which is in agreement with the findings of Oboegbulem and Chah (1997) who reported that although PPR occurs throughout the year more cases were seen during the rainy season or with earlier reports of Marwat (2008) and Hart \& Bussmann (2018), converging that herbs are often used because of their frequent availability, ease of collection and applications. Other studies in some States in Northern Nigeria reported that only $15.31 \%$ of respondents went for orthodox medicine (De Smet, 1998; Neils et al., 2008). This result is also in agreement with reports of Raul et al. (1990), Sori et al. (2004) and Sakaba et al. (2019) that most farmers and pastoralists rely on traditional knowledge and the use of available plants for the treatment of ruminant diseases. It is also in line with Alawa et al. (2002) and Fajimi \& Taiwo (2005) who reported the existence and efficacy of ethnoveterinary practices using available plants in Nigeria. Meanwhile, greater number agreed that orthodox medicine is more effective in treating animal diseases. According to Sori et al. (2004), most pastoralists frequently use herbal preparations to treat their animals, whereas the remaining preferred the complementary use of both herbal preparations and modern drugs. It was observed that the method of 
administering ethno-veterinary plant remedies varied greatly among the different ethnic communities (Bhatti et al., 2017). More so, the fear of orthodox drugs or its scarcity (Mesfin et $a l ., 2009)$ may grow beyond the reach of Nomads and hence, resort to medicinal plants for livestock health need.

Most of the respondents in the study area agreed that local herbs have medicinal value, can be used to treat animals. However some of the plants mentioned in this study contain chemicals that may explain their ethnoveterinary use. For instance, some of the plants influence the immune system or are effective against internal and external parasites (Abdu \& Faya, 2000). Plant parts used for drug preparation include barks, leaves, stems, juices, flowers, bulbs and seeds (Viegi et al., 2003; Jabber et al., 2006; Dilshad et al., 2008). Some ethnoveterinary practices have been reported in Nigeria (Alawa et al., 2002; Alhaji \& Babalobi, 2015; Pakhtunkhwa et al., 2019). Alawa et al. (2002) and Fajimi \& Taiwo (2005) reported the existence and efficacy of ethnoveterinary practices using available plants in Nigeria. Several studies carried out in Africa, Asia, Europe, Latin America and North America show that plants are routinely used as remedy for animal diseases (Lans et al., 2007). Different combinations of plant and other organic materials have been used at the study area to treat skin infections/parasitosis including palm oil, palm kernel oil, engine oil, Khaya senegalensis bark, Nicotiana tabacum leaf etc. Several authors have corroborated the efficacy of these traditional treatments. In small ruminants, Veronia conferia (leaves), palm oil and engine oil are used against fleas, ticks and mange, respectively in Nigeria (Worku, 2018). Rhizome of turmeric was reported to be used for the treatment of mastitis, inflammation, constipation, foot and mouth disease and ectoparasitic infection (Kumar et al., 1993; Rautray et al., 2015). Turmeric paste is used for prevention and treating different skin diseases including fungal infections (Mishra, 2011; Rautray et al., 2015).

The present result agrees with the findings of Kolawole et al. (2007) that palm oil is used to treat scabies (mange). It also corroborates Ojo et al. (2014) whose respondents used Khaya senegalensis and Nicotiana tabacum to treat mange in ruminants in Ekiti State, Nigeria. The use of Aloe spp and Nicotiana tabacum leaves against diseases and parasites aligns with the reports of Moreki et al. (2010). A paste of Nicotiana tabacum leaves is used to treat skin diseases, swelling and scorpion sting (Moreki et al., 2010; Tsouh et al., 2015). Omotara and Olutegbe (2015) also reported the rubbing of the body of the animal with palm kernel oil and salt for lice treatment. The use of Bridelia ferruginea stem bark for the treating of cough aligns with the report of Adeola et al. (2012). The treatment of mastitis using Curcuma longa $\mathrm{L}$ (turmeric) has been validated by Rautray et al. (2015). The use of Khaya senegalensis for the treatment of helminthosis in this survey was corroborated by Bizimana (1994) that gave a number of plants that have anthelmintic properties including Khaya senegalensis (bark), leaves and stems of Securinegar virosa. The use of bitter leaf plants in treating diarrhoea agrees with that of Chah et al. (2009) and the study of Mafimisebi et al. (2012) whereas Chauhan \& Sharma (2018) validated the antidiarrhoeal efficacy of Phyllanthus amarus too. The use of bitter leaf and lime orange drench in this study is in agreement with the study of Omotara \& Olutegbe (2015) in Obokun Local government Area of Osun State. Sakaba et al. (2019) supported the use of Anona senegalensis bark and Diospyrus mespitiformis root for the treatment of snake bite.

\section{CONCLUSION}

Larger proportion of the respondents was males in their productive age. Family, relatives and friends were the major sources of endogenous knowledge in treating diseases of small ruminants. The people used 18 medicinal plants to cure 13 prevalent small ruminant disease conditions. Some important plants like Khaya senegalensis, Nicotiana tabacum, Curcuma longa L, Palm tree, Moringa oleifera, Pawpaw, Phyllanthus amarus, Vernonia amygdalina, Anona senegalensis, Diospyrus mespitiformis etc were used. These plants were cost effective and easily available for treatment of diseases compared to orthodox medicine. PPR was the most encountered disease and feed resources were recorded as the greatest constraint that militated against successful rearing of small ruminants while diseases accounted for most deaths. The current study has contributed to the preservation of indigenous plant-based knowledge from extinction. Phytochemical and pharmacological investigations could be carried out to isolate the active compound(s). Moreover, toxicological investigations are required for safe and secure use of the plants and their products.

\section{CONFLICT OF INTEREST}

There was no conflict of interest.

\section{REFERENCES}

Abbasi, A.M., Khan, S.M., Ahmad, M., Khan, M.A., Quave, C.L. \& Pieroni, A. (2013). Botanical Ethnoveterinary therapies in three districts of Lesser Himalayas of Pakistan. Journal of Ethnobiology and Ethno-medicine, 9(1), 84-88.

Abdu, P.A. \& Faya, J.N. (2000). The efficacy of some Nigerian plants on helminthes found in local chickens. Ethno veterinary practices research and development. Proceedings of an International Workshop on Ethno veterinary practices held 14-18 August, 2000, Kaduna, Nigeria. Pp 65-71.

Abdulhamid, Z., Lawal, U. S., Tahir, A. M., Harande, M. M., Usman, H. \& Nuhu, A. (2017). Perceptions of Hausa and Fulani Tribes on Traditional Birth Attendants in Zaria Local Government Area, Kaduna State, Nigeria. Journal of Complementary 
and Alternative Medical Research (2017) 2(2), 17.

Adedeji, O.S., Akande, T.O., Akinwumi, A.O., Okunlola, D.O. \& Shittu, M.D. (2013). Ethnoveterinary practices among sheep rearers in Ona-Ara Local Government Area of Oyo State, Nigeria. Sokoto Journal of Veterinary Sciences, Volume 11 (1), 3844.

Adeniran, L.A., Okpi, S., Anjorin, T.S. \& Ajagbonna, O.P. (2020). Medicinal plants used in ethnoveterinary practices in the Federal Capital Territory, NorthCentral Nigeria. Journal of Medicinal Plants Research, 14(8), 377-388.

Adeola, A.O., Adewole, S.O. \& Olofintoye, L.K. (2012). Studies on Ethno-veterinary Practice in Ruminants in Ekiti State Nigeria. Research Journal of Agriculture and Environmental Management, 3(12), $632-645$.

Akobundu, I.O., Ekeleme, F., Agyakwa, C.W. \& Ogazie, C.A. (2016). A Handbook of West African Weeds. $3^{\text {rd }}$ Edition, Afkar Printing and Publishing Company Limited, Ogba, Ikeja, Nigeria. $\quad$ Pp 32-34.

Alawa, J.P., Jokthan, G.E. \& Akut, K. (2002). Ethnoveterinary medicine in Nigeria.Preventive Veterinary Medicine, 54 (1), 79-90

Alhaji, N.B. \& Babalobi, O.O. (2015). Participatory Epidemiology of Ethnoveterinary Practices Fulani Pastoralists Used to Manage Contagious Bovine Pleuropneumonia and Other Cattle Ailments in Niger State, Nigeria. Journal of Veterinary Medicine, Volume 2015, Article ID 460408, pp. 110.

Aziz, M.A., Khan, A.H., Adnan, M. \& Ullah, H. (2018). Traditional uses of medicinal plants used by indigenous communities for veterinary practices at Bajaur Agency. Pakistan Journal of Ethnobiology and Ethnomedicines, 14 (1), 11.

Bhatti, R.C., Nirmala, C., Kaur, A., Singh, S., Kumar, P., Kaur, R. \& Sigh, A.N. (2017). Harnessing of local plant species by indigenous people of Hamirpur District for Ethno-veterinary purposes. Annals of Plant Science, 6(12), 1898-1925.

Birhanu, T. \& Abera, D. (2015). Survey of Ethnoveterinary medicinal plants at selected Horro Gudurru Districs, Western Ethiopia. African Journal of Plant Science, 9 (3), 185-192.

Bizimana, N. (1994). Traditional veterinary practice in Africa. Deutsche Gesellschaft fur Zusammenarbeiz. Eschborn, pp 1-917.

Bouyahya, A., Abrini, J., Et-Touys, A., Bakri, Y. \& Dakka, N. (2017). Indigenous knowledge of the use of medicinal plants in the North-West of Morocco and their biological activities. European Journal of Integrative Medicine, 13, 9-25.

Brouwer, N., Liu, Q., Harrington, D., Kohen, J., Vemulpad, S., Jamie, J., Randall, M. \& Randall, D. (2005). Ethno pharmacological Study of Medicinal Plants in New South Wales. Molecules, 10, 1252-1262.

Buwa-komoreng, L.V., Mayekiso, B., Mhinana, Z. \& Adeniran, A.L. (2019). An Ethnobotanical and
Ethnomedicinal Survey of Traditionally Used Medicinal Plants in Seymour, South Africa: An Attempt toward Digitization and Preservation of Ethnic Knowledge. Pharmacognosy Magazine, 15(69), 115-123.

Chah, J.M., Igbokwe, E.M. \& Chah, K.F. (2009). Ethnoveterinary medicine used in small ruminant health in the eastern guinea savanna, Nigeria. Livestock Research and Rural Developement, 21(12), 1-45.

Chauhan, S. S. \& Sharma, H. K. (2018). A pharmacological evaluation of anti-diarrheal activity of aqueous leaves extract of Phyllanthus amarus in experimentally induced diarrhea in rats. World Journal of Pharmaceutical Research, 7(1), 1222 1229.

Chimonyo, M., Kusina, N.T., Hamudikuwanda, H. \& Nyoni, O. (1999). Land use and usage of cattle for draught power in a small holder croplivestock farming system in Zimbabwe. Journal of Applied Science of Spouth Afric,. 5, 111-121.

De Smet, G.M. (1998). Traditional pharmacology and medicine in Africa. Ethnopharmacological themes in sub-Saharan art objects and utensils. Journal of Ethnopharmacology 63(1-2), 1- 175.

Dilshad S.M.R., Rehman N., Iqbal Z., Muhammed G., Iqbal A. \& Ahamd N. (2008). An inventory of the ethnoveterinary practices for reproductive disorders in cattle and buffaloes, Sargodha district of Paskistan. Journal of Ethnopharmacology., 117, 393-402.

Ebbo, A. A., Bello, A., Ismail, M. S., Dauda, A. M., Idris, S. B. \& Sani, A. A. (2019). Ethno-Veterinary Survey of Medicinal Plants used for the Treatment of Diseases in Sheep within Sokoto Metropolis, Nigeria. Direct Research Journal of Health and Pharmacology, 7(1), 1-9.

Efenakpo, O. D., Ayodele, I. A. \& Ijeomah, H. M. (2016). "Assessment of Frog Meat Utilisation in Ibadan, Oyo State, Nigeria". Journal of Research in Forestry, Wildlife and Environment 8(3), 31-43.

Fajimi, A.K. \& Taiwo, A.A. (2005). Herbal remedies in animal parasitic diseases in Nigeria: A review. African Journal of Biotechnology, 4(4), 303-307.

FAO (2016). Economic analysis of animal diseases. In FAO Animal Production and Health Guidelines pp. 18.

Fullas, F. (2010). Ethiopian Medicinal Plants in Veterinary Health Care: A mini review. Ethiopian e-Journal for Research and Innovation Foresight, 2 (1), 48 58.

Gras, A., Parada, M., Rigat, M., Vallès, J. \& Garnatje, T. (2018). Folk medicinal plant mixtures: Establishing a protocol for further studies. Journal of Ethnopharmacology 214, 244-273.

Hart, R. \& Bussmann, R. (2018). Trans-Himalayan Transmission, or Convergence? Stauntonia (Lardizabalaceae) as an Ethnoveterinary Medicine. Medicina nei Secoli., 30(3), 929-948. 
Heinrich, M., Edwards, H.S., Moerman, D.E. \& Leonti, M. (2009). Ethnopharmacological field studies: a critical assessment of their conceptual basis and methods. Journal of Ethnopharmacology, 124, $1-17$.

International Society of Ethnobiology (ISE) (2008). ISE Code of Ethics. Online: http://ethnobiology.net/code-of-ethics/

Jabbar, A., Raza, M.A., Iqbal, Z. \& Khan, M.N. (2006). An inventory of the ethnobotanicals used as anthelmintics in the Southern Punjab, Pakistan. Journal of Ethnopharmacy, 108, 152-154.

Kaikabo, A.A., Mustapha, A. \& Dagona, A.M. (2004). Ethnoveterinary medicine among Bade pastoralists in semi-arid zone of northern Nigeria: Studies on indigenous treatments and management practices (Abstract). African Journal of Extension, 3, 48-69.

Kolawole, O.D., Okorie, V.O., Ogidiowa, M.T. \& Adeogun, M.O. (2007). Ethnoveterinary practices among small-holder farmers in Ekiti State Nigeria, African Journal of Traditional, Complementary and Alternative Medicine, 4(4), 434-442.

Kubkomawa, H., Nafaarnada, D., Adamu, S., Tizhe, M., Daniel, T., Shua, N., Ugwu, C., Opara, M., Neils, J., \& Okoli, I. (2013): Ethnoveterinary health management practice amongst livestock producers in Africa-A review, World Journal of Agriculture Sciences, 1(8), 125-138.

Kumar, A., Sharma, V.K., Singh, H.P., Prem, P. \& Singh, S.P. (1993). Efficacy of some indigenous drugs in tissue repair in buffaloes.. Indian Veterinary Journal, 70, 42-45.

Lans, C., Turner, N., Khan, T., Brauer, G. \& Boepple, W. (2007). Ethnoveterinary medicines used for ruminants in British Columbia, Canada. Journal of Ethnobiology and Ethnomedicine, 3(11), 1-22.

Mafimisebi, T.W., Oguntade, A.E., Fajemisin, A.N. \& Aiyelan, O.P. (2012). Local knowledge and socioeconomic determinants of traditional medicines utilization in livestock health management in Southwest Nigeria, Journal of Ethnobiology and Ethnomedicine, 8 (2), 1-9.

Martin, G.J. (2004). Ethnobotany: A Methods Manual. Earths can Publications Ltd, London. Pp 65.

Marwat, S.K. (2008). Ethnophytomedicines for treatment of various diseases in DI Khan district, Pakistan. Sarhad Journal of Agriculture, 24(2), 305-315.

Mathias-Mundy, E. \& McCorkle, C.M. (1989). Ethno veterinary Medicine: An Annotated Bibliography. Technology and Social Change Program. Iowa State University, AMES. U.S.A.

Menale, B. \& Muoio, R. (2014). Use of medicinal plants in the South-Eastern area of the Partenio Regional Park (Campania, Southern Italy). Journal of Ethnopharmacology 153(1), 297-307.

Mesfin, F., Demissew, S. \& Teklehaymanot, T. (2009). An ethnobotanical study of medicinal plants in Wonago Woreda, SNNPR. Ethiopia. Journal of Ethnobiology and Ethnomedicine, 5 (28), 42-48.
Mishra, D. (2011). Ethnoveterinary practices and use of herbal medicines for treatment of skin diseases in cattle: A study in Polsara block, Ganjam District, Odisha, India. Indian Journal of Traditional Knowledge, 4(6), 250-253.

Mishra, D. (2013). Cattle wound and ethnoveterinary medicine: A study in Polsara block, Ganjam District, Orisha, India. Indian Journal of Traditional Knowledge, 12, 62-65.

Moreki, J.C., Poroga, B., Dikeme, R. \& Sebo, D. (2010). Ethnoveterinary medicine and health management in Poultry in Southern Western District Botswana. Livestock Research for Rural Development 22(6), Article \#107. retrieved July 11, 2021, from http://www.Irrd.Org/Irrd 22/6/more 22107.htm

Mudansiru, A., Zaharaddeen, U., Haidara, A.M. \& Ibrahim, S. (2016). Ethnomedicinal Survey of Some Plants Used for the Treatment of Various Ailments in Gumel Town, Jigawa State, Nigeria. Biology, Agriculture and Healthcare, 6(7), 137-142.

Neils, J.S., Nzalak, J.O., Sackey, A.K.B. \& Okpara, J.O. (2008). Ethno- veterinary practices: The perception among the Fulani cattle reares in Adamawa State, Nigeria. Sokoto Journal of Veterinary Sciences, 7(2), 38-41.

Nnadi, F.N., Umunakwe, P.C., Nnadi, C.D. \& Okafor, O.E. (2012). Socio-economic determinants of farmers' use of ethnoveterinary medicine in Mbaitoli L.G.A of Imo State, Nigeria, Res. J. Agric. Environ. Manag., 1(1), 025-033.

Nok, A.J., Esievo, K.A.N., Longdet, L., Arowosafe, S., Onyenekwe, P.C., Gimba, C.E. \& Kagbu, J.A. (1993). Trypanocidal potentials of Azadirachta indica: in vivo activity of leaf extract against Trypanosoma brucei. J. Clin. Biochem. Nutr., 15, $113-118$.

Nok, A.J. \& Williams, S. (1996). Allium sativum-induced death of African Trypanosomes. Parasit. Res., 82, 634-637.

NPC (2006). "Nigeria National Census: Population Distribution by Sex, State, LGAs and Senatorial District: 2006 Census priority tables (Vol. 3)". National Population Commission, Abuja, Nigeria.

Oboegbulem, S.I. \& Chah, K.F. (1997). Retrospective studies of diseases of goats in Nsukka, Eastern Nigeria. Bulletin of Animal Health and Production of Africa (Kenya), 45, 236-259.

Ocvirk, S., Kistler, M., Khan, S., Talukder, S.H. \& Hauner, H. (2013). Traditional medicinal plants used for the treatment of diabetes in rural and urban areas of Dhaka, Bangladesh. An ethnobotanical survey. Journal of Ethnobiology and Ethnomedicine, 2013, 9-43.

Offor, E.I., Ekweanya, N.M. \& Oleka, A.C. (2018). Effects of socio-economic factors on small ruminant production in Ohafia agricultural zone of Abia State, Nigeria. Journal of Tropical Agriculture, Food, Environment and Extension, 17(3), 7-11.

Ojo, A.A, Adewole, S.O. \& Olofintoye, L.K. (2014). Studies on Ethnoveterinary Practice in Ruminants in 
Ekiti State, Nigeria. Research Journal of Agriculture and Environmental Management, 3(12), 632-645.

Omotara, O. A. \& Olutegbe, N. S. (2015). Use of endogenous knowledge in treating pests and diseases of small ruminants in Obokun Local government Area of Osun State. Nigerian Journal of Rural Sociology, 15(2), 110-115.

Osho, I.B. \& Fasina, O.O. (2013). Small ruminants ownership pattern and level of veterinary consultation under traditional system of management in Ondo and Ekiti State of Nigeria, Russian Journal of Agricultural and SocioEconomic Sciences. 8(20), 27-32.

Pakhtunkhwa, K., Khan, K., Rahman, I.U., Calixto, E.S., Ali, N. \& Ijaz, F. (2019). Ethnoveterinary Therapeutic Practices and Conservation Status of the Medicinal Flora of Chamla Valley, 6(May).

Palling, R. \& Dwinger, R.H. (1993): Potential of trypanotolerance as a contribution to sustainable livestock production in tsetse affected areas of the Africa. The Veterinary Quarterly, 15(2), 60-67.

Rafique, K., Akhter, S.M., \& Hussain, M. (2021). Ethnoveterinary practice for the treatment of animal diseases in Neelum Valley, Kashmir Himalaya, Pakistan. PLoS ONE 16(4), e0250114.

Rahmatullah, M., Mollik, M.A.H., Alam, M.J., Ahmed, B., Jahan, F.I., Sintaha, M., Khaleque, H.N.,

Chowdhury, M.H., Noor, F.A., Rahman, S., Jahan, Rownak \& Seraj, S. (2010). An ethnoveterinary survey of medicinal plants used by folk medicinal practitioner to treat cattle diseases in randomly selected areas of Bagerhat district, Bangladesh, Am.-Eur. J. $\quad$ Sustainable Agric., 4(3), 386-396.

Raul, P., Pedrazo, M. \& Manuela, P. (1990). Animal healthcare in India. Information centre for low external input in sustainable agriculture (ILEIA). Newsletter, 8(3), 22-23.

Rautray, A.K., Sahoo, R., Sardar, K.K., Patra, R.C. \& Sahoo, A. (2015). Ethnoveterinary practices for small ruminants followed by rural folks in southern Odisha. Indian Journal of Traditional Knowledge, 14(2), 319-324.
Safilios, R.C. (1983). Women in sheep and goat production and marketing. FAO expert consultation on Women in Food Production. Rome, Italy. Pp 15-24

Sakaba, A. M. Isgogo, S. M., Hamisu, S. Ardo, A. M. \& Fakai, L. U. (2019). Assessment of Ethnoveterinary Practices among Cattle Herders in Zuru, Kebbi State, Nigeria. Asian Journal of Research in Animal and Veterinary Sciences, 3(1), 1-7.

Sori, T., Bekana, M., Adugna, G. \& Kelbassa, E. (2004). Medicinal plants in the ethno-veterinary practices of Borana pastoralists, Southern Ethiopia. International Journal of Applied Research in Veterinary Medicine, 2(3), 220-225.

Srithi, K., Balslev, H., Wangpakapattanawong, P., Srisanga, P. \& Trisonthi, C. (2009). Medicinal plant knowledge and its erosion among the Mien (Yao) in Northern Thailand. Journal of Ethnopharmacology, $123,335-342$.

Tabuti, J.R.S., Dhillion, S.S. \& Lye, K.A. (2003). Ethnoveterinary for cattle (Bos indicus) in Bulamogi country, Uganda: plant species and mode of use. Journal of Ethnopharmacology, 88, 279286.

Tariq, A., Mussarat, S., Adnan, M., AbdElsalam, N.M., Ullah, R. \& Khan, A.L. (2014). Ethnoveterinary Study of Medicinal Plants in a Tribal Society of Sulaiman Range. The Scientific World Journal, Volume 2014, Article ID 127526, 10 pages,

Tsouh, F.P.V., Nyarko, A.K., Appiah-Opong, R., Tchokouaha, Y.L.R., Addo, P., Asante, I.K. \& Boyom, F.F. (2015). Ethnopharmacological reports on anti-Buruli ulcer medicinal plants in three West African countries. Journal of Ethnopharmacology, 172, 297-311.

Viegi, L., Pieroni, A., Guarrera, P.M. \& Vangelisti, R. (2003). A review of plants used in folk veterinary medicine in Italy as basis for a databank. Journal of Ethnopharmacolology., 89, 221- 244

Worku, T. (2018). Review on Importance of Ethnoveterinary Practices in Pastoral Areas of Ethiopia. International Journal of Research Studies in Biosciences, 6(9), 16-27.
Article history:

Received: July 15, 2021,

Revised: Nov. 19, 2021

Accepted: Dec 6, 2021 